\title{
Association between quantitative varicella-zoster virus antibody levels and zoster reactivation in HIV-infected persons
}

Heather S. Pomerantz ${ }^{1,6 *}$ Xiaohe X ${ }^{2,3}$ James White 2,3 T.S. Sunil2,3,4 Robert G. Deiss, 5,6,7, Anuradha Ganesan 6,7,8, Brian K. Agan ${ }^{6,7}$ and Jason F. Okulicz ${ }^{1,5}$

\begin{abstract}
Background: Varicella-zoster virus (VZV) reactivation is common but difficult to predict in HIV-infected persons. Objective: Since qualitative VZV antibodies can determine past VZV disease or vaccination, we evaluated whether quantitative $V Z V$ antibody levels over time can predict future zoster.
\end{abstract}

Study design: US Military HIV Natural History (NHS) participants with a zoster diagnosis at least 5 years after HIV diagnosis $(n=100)$ were included. Zoster-negative controls $(n=200)$ were matched by age, race, gender, and CD4 count at HIV diagnosis. Repository plasma specimens collected at baseline and prior to zoster diagnosis were evaluated using a quantitative anti-VZV ELISA assay. Differences in quantitative VZV levels were analyzed by Wilcoxon MannWhitney and Fisher's exact tests.

Results: Median CD4 count at HIV diagnosis was similar for cases and controls (535 [IQR 384-666] vs. 523 [IQR 377-690] cells/ $\mu \mathrm{L} ; \mathrm{P}=0.940$ ), but lower for cases at zoster diagnosis (436 [IQR 277-631] vs. 527 [IQR 367-744] cells/ $\mu \mathrm{L} ; \mathrm{p}=0.007$ ). Antiretroviral therapy (ART) use prior to zoster diagnosis was lower for cases (52.0\%) compared to controls (64.5\%; $p=0.025)$. Cases had similar mean VZV antibody levels prior to zoster diagnosis compared to controls [2.25 \pm 0.85 vs. $2.44 \pm 0.96$ index value/optical density (OD) ratio; $p=0.151]$ with no difference in the change in antibody levels over time $(0.08 \pm 0.71$ vs. $0.01 \pm 0.94$ index value/OD per year; $p=0.276)$.

Conclusion: Quantitative VZV antibody levels are stable in HIV-infected persons and do not predict zoster reactivation. Low CD4 count and lack of ART use appear to be better predictors of future zoster diagnosis.

Keywords: HIV, Varicella zoster virus, Military

\section{Background}

Infection with varicella zoster virus (VZV) can cause relapse of disease in those with impaired cell mediated immunity (CMI) known as herpes zoster (HZ) and is seen more frequently in those with HIV infection compared to HIV-uninfected individuals [1]. Overall incidence has decreased with increased use of antiretroviral therapy (ART), but rates still remain high in the HIVinfected population compared to the general population

\footnotetext{
*Correspondence: heather.scheibe@gmail.com

${ }^{1}$ Infectious Disease Service, San Antonio Military Medical Center, San Antonio, USA

Full list of author information is available at the end of the article
}

(628-650 per 100,000 person years $[1,2]$ vs. $150-300$ per 100,000-person-years [3, 4] respectively). Complications of $\mathrm{HZ}$ include bacterial superinfection, post-herpetic neuralgia (PHN), and ocular complications, among others [4]. $\mathrm{PHN}$ is a longterm neuropathic pain syndrome that is difficult to treat and it is estimated to affect $10-20 \%$ of those with $\mathrm{HZ}$ with risk increasing with age [5].

Cell mediated immunity appears to play a role in preventing $\mathrm{HZ}$, as waning $\mathrm{CD} 4$ count is associated with development of HZ [1, 4]. Conversely, effective ART results in immune reconstitution and $C D 4$ gains which reduce the risk of VZV reactivation [6, 7]. Even though the association between reduced CMI and VZV reactivation has been well established, it remains difficult to predict disease, as 
it can occur at any CD4 count, and the risk of $\mathrm{HZ}$ remains high in the HIV-infected population even in the ART era [1]. B cell dysfunction has also been observed in those with HIV $[8,9]$ and can lead to altered antibody response [10]. Clinicians currently use VZV antibody status to determine prior exposure to VZV and help guide vaccine decisions while Varicella vaccine clinical trials have used antibody levels to determine efficacy [11]. It is unclear if these antibody levels wane over time, and what role HIV infection plays in longitudinal quantitative VZV antibody levels.

\section{Objectives}

We retrospectively evaluated VZV antibody titers in HIVinfected persons with and without $\mathrm{HZ}$ in order to determine if VZV antibody levels can be used to predict HZ.

\section{Study design}

The US Military HIV Natural History Study (NHS) is a prospective observational study of HIV-infected military members and beneficiaries. Enrolled participants are $\geq 18$ years of age with documented HIV infection and complete informed consent in this IRB approved study. NHS participants have clinical visits approximately every 6-12 months at select military treatment facilities.

The NHS database was queried for participants with (cases) or without (controls) a HZ diagnosis after HIV diagnosis. In order to assess the change in serum VZV antibody titers over time, only participants with a $\mathrm{HZ}$ diagnosis greater than or equal to 5 years after HIV diagnosis were included. Participants were required to have a serum sample $30-180$ days prior to $\mathrm{HZ}$ diagnosis in addition to a sample at least 3 years prior to documented $\mathrm{HZ}$ infection. A total of 100 cases and 200 controls meeting inclusion criteria and serum sample availability were selected for analysis. Control participants who did not develop HZ were matched by age, race, gender, and CD4 count at time of HIV diagnosis. Participants with negative VZV antibody or receipt of varicella or zoster vaccines were excluded.

Two repository plasma specimens were evaluated using a quantitative anti-VZV ELISA assay (Zeus Scientific, Somerville, NJ). VZV antibody levels are represented

Table 1 Baseline characteristics of military personnel with HIV

\begin{tabular}{|c|c|c|c|c|}
\hline Characteristics & $\begin{array}{l}\text { All } \\
\mathrm{N}=300\end{array}$ & $\begin{array}{l}\text { Cases } \\
\mathrm{N}=100\end{array}$ & $\begin{array}{l}\text { Control } \\
\mathrm{N}=200\end{array}$ & p-value \\
\hline Median age at HIV diagnosis (years) & 28.35 & 28.35 & 28.25 & 0.978 \\
\hline Median time HIV negative to positive (years) & 0.68 & 0.66 & 0.69 & 0.828 \\
\hline Median time HIV diagnosis to 1st ART (years) & 5.41 & 5.78 & 4.82 & 0.078 \\
\hline Gender & & & & 0.611 \\
\hline Male & $282(94 \%)$ & $94(94 \%)$ & $188(94 \%)$ & \\
\hline Female & $18(6 \%)$ & $6(6 \%)$ & $12(6 \%)$ & \\
\hline Race/ethnicity & & & & 0.024 \\
\hline Caucasian & $134(44.7 \%)$ & $47(47 \%)$ & $87(43.5 \%)$ & \\
\hline African-American & $123(41 \%)$ & $36(36 \%)$ & $87(43.5 \%)$ & \\
\hline Hispanic/Puerto Rican/Mexican & $28(9.3 \%)$ & $13(13 \%)$ & $15(7.5 \%)$ & \\
\hline Asian/Pacific Islander & $5(1.7 \%)$ & 0 & $5(2.5 \%)$ & \\
\hline Native American/Alaskan Native & $3(3 \%)$ & $3(3 \%)$ & 0 & \\
\hline Other & $7(2.3 \%)$ & $1(1 \%)$ & $6(3 \%)$ & \\
\hline Median time HIV diagnosis to last study visit (years) & 13.18 & 14.28 & 13.0384 & 0.201 \\
\hline Median time from HIV diagnosis to 1st serum date (years) & 2.18 & 1.38 & 2.53 & 0.009 \\
\hline Median time from HIV diagnosis to 2nd serum date (years) & 6.89 & 6.98 & 6.81 & 0.975 \\
\hline Median CD4 at 1st serum date (cells/ $\mu \mathrm{L})$ & 530 & 534.5 & 523 & 0.940 \\
\hline Median VL at 1 st serum date (log10 copies/mL) & 3.66 & 3.72 & 3.65 & 0.471 \\
\hline Median CD4 at 2nd serum date (cells/ $\mu \mathrm{L})$ & 501 & 436 & 527 & 0.007 \\
\hline Median VL at 2nd serum date (log10 copies/mL) & 2.80 & 3.52 & 2.60 & 0.007 \\
\hline On ART at 1st serum date & & & & 0.075 \\
\hline No & $201(67 \%)$ & $73(73 \%)$ & $128(64 \%)$ & \\
\hline Yes & $99(33 \%)$ & $27(27 \%)$ & $72(36 \%)$ & \\
\hline On ART at 2 nd serum date & & & & 0.025 \\
\hline No & $119(39.7 \%)$ & $48(48 \%)$ & $71(35.5 \%)$ & \\
\hline Yes & $181(60.3 \%)$ & $52(52 \%)$ & $129(64.5 \%)$ & \\
\hline
\end{tabular}


for each sample by a calibration cut-off value which is expressed as index value/OD ratio. Specimen time-points for controls were matched to corresponding cases. Differences in quantitative VZV levels were analyzed by the Wilcoxon Mann-Whitney test and Fisher's Exact test, controlling for time intervals between specimens.

\section{Results}

Participants were predominantly male (94\%) with a median age of 29 [IQR 24-34] years at HIV diagnosis (Table 1). The median CD4 count at HIV diagnosis was similar for cases and controls (535 [IQR 384-666] vs. 523 [IQR 377-690] cells/ $\mu \mathrm{L} ; \mathrm{p}=0.940)$. Cases had a significantly lower CD4 count at the second serum date compared to controls (436 [IQR 277-631] vs. 527 [IQR $367-744$ ] cells $/ \mu \mathrm{L} ; \mathrm{p}=0.007$ ). ART use at HZ diagnosis was also lower at the second serum date for cases compared to controls ( $52 \%$ vs. $64.5 \%$; $\mathrm{p}=0.025)$. At $\mathrm{HZ}$ diagnosis, $60 \%$ of cases were on ART. The median CD4 count and viral load (VL) at time of VZV diagnosis were 443 cells $/ \mu \mathrm{L}$ and $3.51 \log _{10}$ copies $/ \mathrm{mL}$, respectively.

Cases had similar mean VZV antibody levels prior to $\mathrm{HZ}$ diagnosis compared to controls $(2.25 \pm 0.85$ vs. $2.44 \pm 0.96$ index value/OD; $\mathrm{p}=0.151$ ) and there was no difference in the change in VZV antibody levels over time $(0.08 \pm 0.71$ vs. $0.01 \pm 0.94$ index value/OD per year; $p=0.276$ ). The range of values for cases was similar to controls [IQR 1.7-2.9 index value/OD vs. 1.7-3 index value/OD]. However, the mean antibody level was higher for those on ART (2.48 index value/OD) compared to those who were not on ART (2.26 index value/OD) with $\mathrm{SD}$ of 0.89 and $\mathrm{p}<0.05$ (Table 2). When evaluating the change in antibody level over time, those with HIV diagnosis for greater than 7 years had a small but significant increase in antibody level over time by 0.03 index value/OD per year compared to those with a diagnosis of HIV for less than 7 years (decrease of 0.04 index value/OD per year) (Table 3 ).

\section{Discussion}

Although VZV antibody can identify exposure to Varicella infection or past immunization, we found that neither the magnitude of VZV antibody level nor the change in concentration over time predicted $\mathrm{HZ}$ reactivation in HIV-infected persons. CMI most likely plays a larger role in immune protection from $\mathrm{HZ}$ and may be a better predictor of HZ than VZV antibodies, however the latter have been shown to be important as described below. Markers of intact CMI are associated with reduced incidence of $\mathrm{HZ}$ and reduced PHN $[12,13]$. The zoster vaccine increases the number of
VZV specific CD4+ T cells [14] and older adults have an increase in IFN $\gamma$ after a second dose of vaccine [15]. However, the only marker of CMI assessed clinically is CD4 count which is associated with development of $\mathrm{HZ}$ but not always predictive. For example, a higher prevalence of $\mathrm{HZ}$ has been observed in those with VL suppression and CD $4>750$ cells/ $\mu \mathrm{L}$ compared to HIVuninfected persons $[1,7,16]$.

In addition to a T-cell mediated immune response, humoral response also appears to be important as VZV antibodies have been used to demonstrate vaccine effectiveness [11, 17-19]. A study analyzed gpELISA VZV antibody prior to immunization and at week 6 after immunization and found that $100 \%$ rise (onefold) in levels better correlated with protection against $\mathrm{HZ}$ rather than antibody level alone irrespective of baseline level [20]. Additionally, varicella zoster immune globulin (VZIG) is given to allow passive immunity and is currently recommended in those with high risk exposure [21]. Currently there is a licensed vaccine to prevent the occurrence of $\mathrm{HZ}$ and reduce the complications such as PHN $[17,21]$. However, this is only FDA approved for those over age 50 and is contraindicated in HIV infected individuals with a CD4 count less than 200 cells/ $\mu \mathrm{L}[21,22]$.

\begin{tabular}{|c|c|c|c|}
\hline & $\begin{array}{l}\text { Mean index } \\
\text { value/OD (n) }\end{array}$ & SD & T-test \\
\hline \multicolumn{4}{|c|}{ On ART at second serum } \\
\hline No & $2.26(119)$ & 0.89 & $-2.08^{*}$ \\
\hline Yes & $2.48(180)$ & 0.93 & $-2.08^{*}$ \\
\hline \multicolumn{4}{|c|}{ Duration of HIV infection at second serum (years) } \\
\hline$<7$ & $2.38(153)$ & 0.95 & -0.30 \\
\hline $7+$ & $2.41(146)$ & 0.89 & -0.30 \\
\hline \multicolumn{4}{|c|}{ Viral load at second serum (log10 copies/mL) } \\
\hline$<400$ & $2.41(127)$ & 0.87 & 0.20 \\
\hline $400+$ & $2.38(170)$ & 0.95 & 0.20 \\
\hline \multicolumn{4}{|c|}{ CD4 at second serum (cells/ $\mu \mathrm{L})$} \\
\hline$<500$ & $2.42(149)$ & 0.97 & 0.56 \\
\hline $500+$ & $2.36(149)$ & 0.87 & 0.56 \\
\hline \multicolumn{4}{|c|}{ CD4 at HIV diagnosis (cells/ $\mu \mathrm{L}$ ) } \\
\hline$<500$ & $2.45(111)$ & 0.88 & 0.90 \\
\hline $500+$ & $2.34(157)$ & 0.97 & 0.90 \\
\hline \multicolumn{4}{|c|}{ Age at HIV diagnosis (years) } \\
\hline$<30$ & $2.40(174)$ & 0.98 & 0.09 \\
\hline $30+$ & $2.39(125)$ & 0.82 & 0.09 \\
\hline \multicolumn{4}{|c|}{ Age at VZV infection (years) } \\
\hline$<40$ & $2.27(59)$ & 0.97 & 0.32 \\
\hline $40+$ & $2.22(40)$ & 0.65 & 0.32 \\
\hline
\end{tabular}


Table 3 Average VZV level change per year subgroup analysis

\begin{tabular}{|c|c|c|c|}
\hline & $\begin{array}{l}\text { Mean index } \\
\text { value/OD (n) }\end{array}$ & SD & T-test \\
\hline \multicolumn{4}{|c|}{ On ART at second serum } \\
\hline No & $0.03(119)$ & 0.21 & 1.58 \\
\hline Yes & $-0.01(180)$ & 0.25 & 1.58 \\
\hline \multicolumn{4}{|c|}{ Duration of HIV infection at second serum (years) } \\
\hline$<7$ & $0.04(153)$ & 0.27 & $2.45^{*}$ \\
\hline $7+$ & $-0.03(146)$ & 0.19 & $2.45^{*}$ \\
\hline \multicolumn{4}{|c|}{ Viral load at second serum (log10 copies/mL) } \\
\hline$<400$ & $0.01(127)$ & 0.21 & -0.01 \\
\hline $400+$ & $0.01(170)$ & 0.25 & -0.01 \\
\hline \multicolumn{4}{|c|}{ 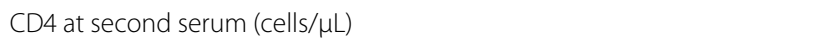 } \\
\hline$<500$ & $-0.01(149)$ & 0.27 & -1.02 \\
\hline $500+$ & $0.02(149)$ & 0.19 & -1.02 \\
\hline \multicolumn{4}{|c|}{ CD4 at HIV diagnosis (cells/ $\mu \mathrm{L}$ ) } \\
\hline$<500$ & $0.00(111)$ & 0.25 & -0.09 \\
\hline $500+$ & $0.01(157)$ & 0.22 & -0.09 \\
\hline \multicolumn{4}{|c|}{ Age at HIV diagnosis (years) } \\
\hline$<30$ & $0.01(174)$ & 0.25 & -0.02 \\
\hline $30+$ & $0.01(125)$ & 0.21 & -0.02 \\
\hline \multicolumn{4}{|c|}{ Age at VZV infection (years) } \\
\hline$<40$ & $0.01(59)$ & 0.17 & 0.12 \\
\hline $40+$ & $0.01(40)$ & 0.14 & 0.12 \\
\hline
\end{tabular}

* indicates $p<0.05$

In the population with HIV infection, the risk for $\mathrm{HZ}$ exists even in those less than the age of 40 [6] and it would be helpful to have a marker that can predict who will develop HZ as they may benefit from vaccination even if not in the current recommended age range. Although our study showed no association between VZV antibody levels and clinical HZ in an HIV-infected population, we validated findings from prior studies demonstrating that that lower CD4 count and lack of ART use were risk factors for the development of HZ. Other risk factors described in this population include high VL and prior history of HZ [6, 7]. In order to reduce the morbidity associated with $\mathrm{HZ}$ in HIV-infected persons, additional clinical markers of risk are needed as well as VZV vaccine safety and efficacy studies in younger patients with preserved CD4 counts.

\section{Authors' contributions}

All authors participated in the design of the study and manuscript preparation. HSP wrote the concept sheet, collected the data and was the main author the paper. XX and JW performed the statistical analysis. TSS, RGD, AG, and BKA help maintain the NHS database, gave demographic information, and reviewed the protocol and made edits to the manuscript. JFO was the primary investigator and helped with study design and edited the manuscript as well. All authors read and approved the final manuscript.

\section{Author details}

${ }^{1}$ Infectious Disease Service, San Antonio Military Medical Center, San Antonio, USA. ${ }^{2}$ School of Public Administration, Sichuan University, Chengdu, China. ${ }^{3}$ Department of Sociology, University of Texas San Antonio, San Antonio, TX, USA. ${ }^{4}$ TX Institute for Health Disparities Research, University of Texas at San Antonio, San Antonio, TX, USA. ${ }^{5}$ Division of Infectious Diseases, Naval Medical Center San Diego, San Diego, CA, USA. ${ }^{6}$ Infectious Disease Clinical Research Program, Preventive Medicine and Biostatistics Department, Uniformed Services University, Bethesda, MD, USA. ${ }^{7}$ Henry M. Jackson Foundation for the Advancement of Military Medicine, Bethesda, MD, USA. ${ }^{8}$ Walter Reed National Military Medical Center, Bethesda, MD, USA.

\section{Acknowledgements}

The contents of this publication are the sole responsibility of the authors and do not necessarily reflect the views, opinions or policies of Uniformed Services University of the Health Sciences (USUHS), the Department of Defense (DoD), or the Departments of the Army, Navy, or Air Force. Mention of trade names, commercial products, or organizations does not imply endorsement by the U.S. Government.

\section{Competing interests}

The authors declare that they have no competing interests.

\section{Consent for publication}

This study is IRB approved and full complete consent was obtained.

\section{Ethics approval and consent to participate}

This study is IRB approved and full complete consent was obtained.

\section{Funding}

Support for this work (IDCRP-000-03) was provided by the Infectious Disease Clinical Research Program (IDCRP), a Department of Defense (DoD) program executed through the Uniformed Services University of the Health Sciences. This project has been funded in whole, or in part, with federal funds from the National Institute of Allergy and Infectious Diseases, National Institutes of Health (NIH), under Inter-Agency Agreement Y1-Al-5072.

\section{Publisher's Note}

Springer Nature remains neutral with regard to jurisdictional claims in published maps and institutional affiliations.

Received: 25 April 2018 Accepted: 29 November 2018

Published online: 11 December 2018

\section{References}

1. Grabar S, Tattevin P, Selinger-Leneman H, de La Blanchardiere A, de Truchis P, Rabaud C, et al. Incidence of herpes zoster in HIV-infected adults in the combined antiretroviral therapy era: results from the FHDH-ANRS CO4 cohort. Clin Infect Dis. 2015;60:1269-77.

2. Wood SM, Shah SS, Steenhoff AP, Rutstein RM. Primary varicella and herpes zoster among HIV-infected children from 1989 to 2006. Pediatrics. 2008;121:e150-6.

3. Donahue JG, Choo PW, Manson JE, Platt R. The incidence of herpes zoster. Arch Intern Med. 1995;155:1605-9.

4. Gebo KA, Kalyani R, Moore RD, Polydefkis MJ. The incidence of, risk factors for, and sequelae of herpes zoster among HIV patients in the highly active antiretroviral therapy era. J Acquir Immune Defic Syndr. 1999;2005(40):169-74.

5. Gialloreti LE, Merito M, Pezzotti P, Naldi L, Gatti A, Beillat M, et al. Epidemiology and economic burden of herpes zoster and post-herpetic neuralgia in Italy: a retrospective, population-based study. BMC Infect Dis. 2010;10:230.

6. Shearer K, Maskew M, Ajayi T, Berhanu R, Majuba P, Sanne I, et al. Incidence and predictors of herpes zoster among antiretroviral therapynaive patients initiating HIV treatment in Johannesburg, South Africa. Int J Infect Dis. 2014;23:56-62.

7. Lee YC, Hung CC, Tsai MS, Zhang JY, Wu PY, Yang SP, Luo YZ, Chang HY, Liu WC, Sun HY, Chang SC. Incidence and risk factors of herpes zoster 
in human immunodeficiency virus-positive patients initiating combination antiretroviral therapy in Taiwan. J Microbiol Immunol Infect. 2018;51(1):38-44

8. Lane HC, Masur H, Edgar LC, Whalen G, Rook AH, Fauci AS. Abnormalities of B-cell activation and immunoregulation in patients with the acquired immunodeficiency syndrome. N Engl J Med. 1983;309:453-8.

9. Pensieroso S, Galli L, Nozza S, Ruffin N, Castagna A, Tambussi G, et al. B-cell subset alterations and correlated factors in HIV-1 infection. AIDS. 2013;27:1209-17.

10. Kohler I, Kouyos R, Bianchi M, Grube C, Wyrzucki A, Gunthard HF, et al. The impact of vaccination on the breadth and magnitude of the antibody response to influenza A viruses in HIV-infected individuals. AIDS. 2015;29:1803-10

11. Breuer J, Schmid DS, Gershon AA. Use and limitations of varicella-zoster virus-specific serological testing to evaluate breakthrough disease in vaccinees and to screen for susceptibility to varicella. J Infect Dis. 2008;197(Suppl 2):S147-51.

12. Asada H, Nagayama K, Okazaki A, Mori Y, Okuno Y, Takao Y, et al. An inverse correlation of VZV skin-test reaction, but not antibody, with severity of herpes zoster skin symptoms and zoster-associated pain. J Dermatol Sci. 2013;69:243-9.

13. Weinberg A, Zhang JH, Oxman MN, Johnson GR, Hayward AR, Caulfield $\mathrm{MJ}$, et al. Varicella-zoster virus-specific immune responses to herpes zoster in elderly participants in a trial of a clinically effective zoster vaccine. J Infect Dis. 2009;200:1068-77.

14. Patterson-Bartlett J, Levin MJ, Lang N, Schodel FP, Vessey R, Weinberg A. Phenotypic and functional characterization of ex vivo T cell responses to the live attenuated herpes zoster vaccine. Vaccine. 2007;25:7087-93.
15. Levin MJ, Schmader KE, Pang L, Williams-Diaz A, Zerbe G, Canniff J, et al. Cellular and humoral responses to a second dose of herpes zoster vaccine administered 10 years after the first dose among older adults. J Infect Dis. 2016;213:14-22.

16. Glesby MJ, Hoover DR, Tan T, Shi Q, Gao W, French AL, et al. Herpes zoster in women with and at risk for HIV: data from the Women's Interagency HIV Study. J Acquir Immune Defic Syndr. 1999;2004(37):1604-9.

17. Levin MJ, Schmader KE, Gnann JW, McNeil SA, Vesikari T, Betts RF, et al. Varicella-zoster virus-specific antibody responses in 50-59-year-old recipients of zoster vaccine. J Infect Dis. 2013;208:1386-90.

18. Oxman MN, Levin MJ, Johnson GR, Schmader KE, Straus SE, Gelb LD, et al. A vaccine to prevent herpes zoster and postherpetic neuralgia in older adults. N Engl J Med. 2005;352:2271-84.

19. Russell AF, Parrino J, Fisher CL Jr, Spieler W, Stek JE, Coll KE, et al. Safety, tolerability, and immunogenicity of zoster vaccine in subjects on chronic/ maintenance corticosteroids. Vaccine. 2015;33:3129-34.

20. Gilbert PB, Gabriel EE, Miao X, Li X, Su SC, Parrino J, et al. Fold rise in antibody titers by measured by glycoprotein-based enzyme-linked immunosorbent assay is an excellent correlate of protection for a herpes zoster vaccine, demonstrated via the vaccine efficacy curve. J Infect Dis. 2014;210:1573-81.

21. Harpaz R, Ortega-Sanchez IR, Seward JF. Prevention of herpes zoster: recommendations of the Advisory Committee on Immunization Practices (ACIP). MMWR Recomm Rep. 2008;57:1-30 (quiz CE2-4).

22. Hales CM, Harpaz R, Ortega-Sanchez I, Bialek SR. Update on recommendations for use of herpes zoster vaccine. MMWR Morb Mortal Wkly Rep. 2014;63:729-31.
Ready to submit your research? Choose BMC and benefit from:

- fast, convenient online submission

- thorough peer review by experienced researchers in your field

- rapid publication on acceptance

- support for research data, including large and complex data types

- gold Open Access which fosters wider collaboration and increased citations

- maximum visibility for your research: over 100M website views per year

At BMC, research is always in progress.

Learn more biomedcentral.com/submissions 